\section{Prevalencia de leptospirosis en perros vagos}

Sr. Editor:

El reciente reporte sobre la prevalencia of leptospirosis en perros vagos es muy interesante ${ }^{1}$. Tuemmers y cols., concluyen que "La prevalencia de leptospirosis fue de $21,3 \%$ " y que "La alta prevalencia hallada demuestra la necesidad de mayores estudios con miras a una mayor comprensión de la epidemiología de la enfermedad y establecer medidas de prevención y control ${ }^{1}$ ". En realidad, usualmente se olvida la importancia de los perros como fuente de infección para el humano. De hecho, la leptospirosis canina, es considerada la segunda fuente de infección en humanos en Tailandia ${ }^{2}$. La seropositividad entre perros callejeros en Tailandia tiene una prevalencia sobre $11 \%{ }^{3}$. En la experiencia del autor, los perros errantes abandonados en templos budistas en Tailandia tienen diversas infecciones. Por ejemplo, existe una alta prevalencia de toxoplasmosis en perros, en correspondencia con la seropositividad en humanos que viven en dichas áreas, los monjes budistas ${ }^{4}$. Por tanto, no cabe duda que el control de una potencial zoonosis en perros es de suma importancia.

\section{Referencias bibliográficas}

1.- Tuemmers C, Lüders C, Rojas C, Serr M, Espinoza R, Castillo C. Prevalence of leptospirosis in vague dogs captured in Temuco city, 2011. Rev Chilena Infectol 2013; 30 (3): 252-7.

2.- Heisey G B, Nimmanitya S, Karnchanachetanee C, Tingpalapong M, Samransamruajkit S, Hansukjariya P, et al. Epidemiology and characterization of leptospirosis at an urban and provincial site in Thailand. Southeast Asian J Trop Med Public Health 1988; 19 (2): 317-22.

3.- Meeyam T, Tablerk P, Petchanok B, Pichpol D, Padungtod P. Seroprevalence and risk factors associated with leptospirosis in dogs. Southeast Asian J Trop Med Public Health 2006; 37 (1): 148-53.

4.- Prevalence of toxoplasmosis among Buddhist monks. Southeast Asian J Trop Med Pub Health 2004; 35 (Suppl 1): 35-6.

Viroj Wiwanitkit Profesor Visitante, Hainan Medical University, China; Profesor Adjunto, Joseph Ayobabalola University, Nigeria; Profesor Visitante, Faculty of Medicine, University of Nis, Serbia

Correspondencia a:

\section{Prevalence of leptospirosis in vague dogs}

Sir, the recent report on prevalence of leptospirosis in vague dogs is very interesting ${ }^{1}$. Tuemmers et al. concluded that "The prevalence of leptospirosis was $21.3 \% 1$ " and concluded that "The high prevalence found demonstrates the need for further studies to better understand the epidemiology of the disease and to establish prevention and control measures ${ }^{1}$ ". In fact, dogs are usually forgotten for its importance as a source of diseases that can infect human beings. Focusing on the leptospirosis in dogs, it is also accepted as the second most common source of human infection in Thailand ${ }^{2}$. Seropositivity among wandering dogs in Thailand has the prevalence rate upto $11 \%{ }^{3}$. In the author's experience, wandering dogs left in Buddhist temple in Thailand have many infections. For example, the high prevalence of toxoplasmosis in dogs can be seen and this corresponds with the positive serology in human living in that area, the Buddhist monks ${ }^{4}$. Hence, it is no doubt that control of possible zoonosis from dogs is very important.

\section{References}

1.- Tuemmers C, Lüders C, Rojas C, Serr M, Espinoza R, Castillo C. Prevalence of leptospirosis in vague dogs captured in Temuco city, 2011. Rev Chilena Infectol 2013; 30 (3): 252-7.

2.- Heisey G B, Nimmanitya S, Karnchanachetanee C, Tingpalapong M, Samransamruajkit S, Hansukjariya P, et al. Epidemiology and characterization of leptospirosis at an urban and provincial site in Thailand. Southeast Asian J Trop Med Public Health 1988; 19 (2): 317-22.

3.- Meeyam T, Tablerk P, Petchanok B, Pichpol D, Padungtod P. Seroprevalence and risk factors associated with leptospirosis in dogs. Southeast Asian J Trop Med Public Health 2006; 37 (1): 148-53.

4.- Prevalence of toxoplasmosis among Buddhist monks. Southeast Asian J Trop Med Pub Health 2004; 35 (Suppl 1): 35-6.

Viroj Wiwanitkit Visiting Professor, Hainan Medical University, China; adjunct professor, Joseph ayobabalola University, Nigeria; visiting professor, Faculty of Medicine, University of Nis, Serbia 